\title{
ADDRESS AT A MEMORIAL SERVICE
}

\author{
BY \\ SIR ROBERT HUTCHISON, Bt., M.D., F.R.C.P.
}

We are met here to-day, all of us friends and many of us colleagues of George Frederic Still, in testimony of our sorrow at his passing, but also in proud recollection of his work and character. This is not the time to speak of his professional achievements; it is enough to say that he was universally recognized, not only in this country but throughout the world, as a master in that branch of medicine to which he devoted himself. This mastery was the result not only of his great intellectual gifts but also of the unwearied diligence and thoroughness of his work as a children's doctor; it was a triumph of character as much as of brains.

But to-day we would rather think of our friend as we knew him as a man. Shy and reticent we all knew him to be and one who did not wear his heart upon his sleeve, but those whom he admitted to his friendship found him a warmhearted human being of infinite kindness and generosity. No one, moreover, could know him even slightly without being impressed by the high principles which guided his every action and how impossible it was to associate him with anything common or mean. It is only right, speaking in this place, to recognize that these high principles were deep-rooted in a simple and sincere religious faith, and it is surely fitting that he should have been laid to rest within the precincts of that Cathedral from whose ritual he derived so much joy and comfort in his late years. Like the Master in Whose footsteps he tried to follow he was the friend of little children; he ministered to them in their sickness, he loved them and was loved by them in return and no man can desire a better epitaph than that. Let us then remember his life's labours with thankfulness and let us all, and especially the younger of us, take encouragement from his example.

But our friend was not only a great doctor and man of science, he was also a poet for whom the common things of life were transmuted by the poet's vision. Shortly before his death he published a little book of his poems, mostly, as was natural, about childhood, and I should like to end by reading to you one which sets out very beautifully and simply, the memory of himself which he wished-and which we may all wish-to leave behind. It is called 'Life's Aftermath.'

When I shall die and in the quiet earth Am laid to rest,

Will there remain some breath of aftermath Of worst or best,

Some potency of evil or of good, Its source unguessed,

From words or deeds, remembered or forgot, A life's bequest? 


\section{ADDRESS AT A MEMORIAL SERVICE}

God in his mercy grant that all the wrong May cease to be,

Not only be forgiven but blotted out, That so of me,

Shall nothing live that might work other's ill, No legacy

Of harm to lead one single soul astray, -Thus may it be, When I shall die.

Can any of us who knew and loved him doubt that so it will indeed be with him as long as his memory remains? 